\title{
RESPIRATORY FUNCTION AND DISEASE AMONG WORKERS IN ALKALINE DUSTS*
}

\author{
BY \\ C. P. CHIVERS \\ From Imperial Chemical Industries Ltd., Alkali Division
}

(RECEIVED FOR PUBLICATION JANUARY 21, 1957)

\begin{abstract}
Little is known of the possible effects of sodium carbonate dust on the lower respiratory passages. A large alkali industry, with a number of works, was used for an investigation of lime and soda ash dusts evolved during the process. The physical and chemical characteristics of these dusts and details of the type of work and environmental conditions are described. In 1954 and 1956 a survey was made of respiratory sickness absence, chest radiographic appearance, and respiratory function in workers employed in areas with exposure to soda ash, lime dust, and no dust. All were interrogated about their smoking habits. In 1954 there was found to be a significant reduction in expiratory flow rate of workers in dusty jobs in soda ash compared with the group not exposed to dust but this result was nullified in a random sample group in 1955 and in full groups in 1956. Respiratory sickness absence was found to be slightly greater in workers in dusty occupations, particularly in lime dust. No pneumoconiosis was detected on miniature films. The survey of smoking habits revealed that smoking was associated with a definite decrease in the expiratory flow rate, particularly after the age of $\mathbf{4 0}$ in heavy smokers. It was concluded that smoking habits played a more important part than alkaline dusts in the reduction of respiratory efficiency as measured by a study of sickness absence and performance of a simple spirometric test.
\end{abstract}

The irritant effect of sodium carbonate dust on the nasal mucous membrane was shown by Archibald (1954). Chronic inflammatory disease of the larynx from exposure to this dust was found by Profazio and Troisi (1953). However, no reports have been published on the possible effects of sodium carbonate dust or soda ash on the lower respiratory passages. Soda ash might be expected to produce a reaction on the mucous membranes of the lower respiratory tract. Despite the filtering action of the nasal cilia, small particles are likely to adhere to the walls of the bronchi, or indeed, enter the alveoli. Soda ash in aqueous solution is strongly alkaline $(\mathrm{pH} 11.6$ to 12) and as the ciliated columnar-celled mucous membrane of the bronchi is identical with that of the larynx, a chemical inflammation might well result. Lime, being both alkaline and, when burnt, soluble, should produce a like effect. Doig (1955) found eight cases of pneumoconiosis in limestone workers who had been exposed to mixed dust containing silica. Although considered to be due to limestone these cases were primarily of silicosis.

* This paper is an abridged version of the essay which won the Occupational Health Prize of the British Medical Association, 1957.
Bridge Davis and Nagelschmidt (1956) carried out clinical and radiographic examinations of 14 men who had worked in pure limestone for periods varying from 12 to 35 years; no evidence of pneumoconiosis was found although the dust counts showed many thousands of particles between 0.5 and $5 \mu$ in the atmosphere to which the men were exposed. Raymond et al. (1952) in 41 limestone quarrymen found no evidence of respiratory disability, though chronic bronchitis and emphysema were recorded. Cement, which is calcined limestone, was investigated by Gardner, Durkan, Brumfiel, and Sampson (1939) and no disability was found in workers exposed to dust in the grinding process. Sander (1958) surveyed again 195 cement workers who had been included in Gardner's original survey and who had had from 20 to 45 years of exposure to cement dust. There were minor changes (" linear exaggeration") in the chest radiographs of those exposed to raw or mixed cement dust, but in those exposed to finished cement dust alone there were no recognizable changes in the chest radiographs even after upwards of 30 years' exposure. Symptomless perforation of the nasal septum in cement workers was found by Marchand (1944). Hunter 
(1955) mentions harmless arborescent markings in chest radiographs of workers in limestone quarries.

The Registrar General's Decennial Supplement on Occupational Mortality (1931) gave the standardized mortality ratio (S.M.R.) for chemical workers as 80. In the 1951 Supplement the S.M.R. for chemical workers is given as 85 . An analysis of the mean annual death rate from all causes per 100,000 and the ratio of death rate to that of all males taken as 100 indicates that chemical workers of all ages, except 70 to 75 , have a relatively favourable mortality. No mortality data specific to the alkali industry are available. Respiratory mortality was lower in chemical workers than in other workers generally.

These studies on the two dusts which are most prevalent in the mid-Cheshire alkali industry suggested the need for an enquiry into the functioning of the lower respiratory tract of workers exposed to these dusts, and the possible existence of any unusual or excessive morbidity attributable to them.

\section{Type of Works}

The mid-Cheshire alkali industry is largely carried on in four works: one large (A); two medium-sized (B) and (C); and one small (D). Works A, B, and C are within one mile of a town of 35,000 inhabitants which has no other major industry. Works $D$ is in open country three miles from the town. The approximate total numbers employed are:

\begin{tabular}{c|c|c}
\hline Works & $\begin{array}{c}\text { Approximate No. of } \\
\text { Pay Roll Workers }\end{array}$ & $\begin{array}{c}\text { Dusts Involved in } \\
\text { Process }\end{array}$ \\
\hline A & 2,500 & Lime \\
B & 1,000 & Ash and lime \\
C & 700 & Ash and lime \\
Dil
\end{tabular}

These numbers include all employees on the pay roll. Thus the men under consideration, namely those continually exposed to the dust in certain areas in the works A, B, and C, were only a small proportion of the total (Table 1).

At works A caustic soda and its by-products and at works $B$ and $C$ sodium carbonate and its byproducts are made. The three alkali works (A, B, and $\mathrm{C}$ ) produced lime dust, either as limestone or burnt lime, and sodium carbonate dust as a result of part of the process. At works D where brine is won through holes in the earth, there is no dust and the workers here therefore served as controls.

\section{Type of Work}

Soda ash manufacture has been carried out for over 75 years and caustic soda manufacture for over 40 years in this district. The three raw materials (brine, limestone, and coke) are used in a chemical reaction with ammonia (derived from gas works crude liquor) to produce sodium bicarbonate. This is calcined to produce sodium carbonate (soda ash) or reacted with lime to produce caustic soda. No fundamental alterations in this industry have occurred since it started and the only changes in the exposure of men to the dusts under consideration have been a gradual reduction in the evolution of dust and a better extraction of the dust which found its way into the atmosphere.

The process is continuous and therefore all workers on it have to work on a shift rota, whereas those handling the finished product or raw materials need only work by day. The workmen in the lime areas at works $\mathrm{A}, \mathrm{B}$, and $\mathrm{C}$ work three shifts and their job is to despatch from stock quantities of limestone (calcium carbonate) to the kilns where it is burned with coke to form burnt lime (calcium oxide) and to dissolve the burnt lime to form milk of lime (calcium hydroxide). At the times during the shift when lime and limestone are conveyed on bands, the atmosphere in the kilns where the men are working is noticeably dusty. The lime bands run during all the shift except for half an hour, and the limestone band runs for two to three hours per shift. Little, if any, dust comes from the coke which is added in small quantities to the limestone at an early stage.

Workers in soda ash may be divided into two groups. One deals with the packing and loading of 1 to 2 cwt. bags of soda ash. The second reclaims jute bags which have been soiled and caked with soda ash. Physical demands are greater in both these groups than in those on process work and dust exposure is both heavy and prolonged. Many of the men employed in the soda ash areas, the bag packers, bag stitchers, and handlers of contaminated bags, do not move about much during their work; the concentration of dust inhaled is thus greater and more constant than in the lime area.

Works $\mathrm{D}$ is mainly concerned with the erection, maintenance, and working of brine boreholes. The erection and maintenance is done by day workers, but approximately 20 shiftmen are needed to look after the bore holes at night. Physical fitness is needed, as much of the work involves the use of weighty tackle and there is very little protection from weather.

\section{Dusts Produced}

The dusts are chemically of two groups: lime (calcium carbonate and oxide) and soda ash (sodium carbonate). All of them are white, flocculent and anhydrous. The alkalinities of the dusts are:

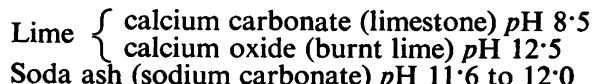


The varieties of soda ash (light, dense, and granular) are chemically identical but vary in structure. The dusts at the various sampling places are microscopically similar.

Chemical analysis revealed that the silica content of limestone varied from 0.35 to $0.42 \%$ at the different works and was approximately $2.8 \%$ when the limestone was burned to produce calcium oxide. Soda ash contained no silica.

\section{Method of Survey}

Selection of Test Method.-Simple tests of respiratory function have been used in the assessment of disability in pneumoconiosis for a number of years. Garrad (1949) using the vital capacity, investigated Cornish tin-miners. More modern tests, including the maximum breathing capacity test and gas distribution and transfer estimations, have been utilized by Motley, Lang, and Gordon (1949) and Gilson, Hugh-Jones, Oldham, and Meade (1955) on miners with varying degrees of disability. Kazantzis and Buxton (1956) used the maximum breathing capacity test (M.B.C.) and both the conventional vital capacity and the expiratory fast vital capacity tests in a survey of the respiratory function of men casting cadmium alloys.

The test described by Kennedy (1953), using a graphic method of recording a tracing on a moving drum, is short and simple and needs little effort or cooperation on the part of the subject. The expiratory flow rate at 40 breaths/min., i.e., "the timed vital capacity" or " expiratory fast vital capacity" (E.F.R.) showed a correlation of +0.927 with the maximum breathing capacity. The standard error of $5.951 . / \mathrm{min}$. on single tracings, compared with a mean of $2.431 . / \mathrm{min}$. averaged over six tracings, indicated a high degree of reproducibility. This test was therefore adopted.

Every effort was made to obtain as many volunteers as possible for the respiratory tests but nevertheless the lapse rate was regrettably high. The morbidity and radiographic findings were not obtained directly from the men, though their cooperation was required in filling up the questionnaire on smoking. The men who were on incentive bonus were given the assurance of the management that no loss of pay would result from time spent away from work while undergoing tests. The tests were undertaken at the most convenient time of day and at a site near the work. As only a very small number of employees working in soda ash and lime are women (approximately 20) only men were included in the investigation. All volunteers, between 20 and 70 years of age, were allowed to undergo the test, though some of them were known to have respiratory disabilities of long standing.

Many of the volunteers for the respiratory function test also volunteered for a routine mass miniature radiograph (M.M.R.) at works A. No pneumoconiosis was found, but simple pneumoconiosis cannot, of course, be detected with reliability on small films.

\section{Lapsed Volunteers}

Table 1 shows the number of volunteers and lapsed employees in 1954 together with the total possible in each exposure group. Certain results were inconsistent and in 1956 all employees in the designated areas were therefore again encouraged to volunteer. Table 2 shows the distribution of the 1956 group; the lapse rate was unfortunately high.

The average age in both volunteers and lapsed groups (Table 3 ) shows slight variability except in the 1954 "no-dust lapsed group", which is markedly high because of the inclusion of nine men over the age of $60^{*}$.

* (1) The differences shown in numbers of attacks per man are not large enough to prove any systematic difference between the lapsed and volunteer groups.

(2) There is no evidence that the number of weeks' absence per attack differs amongst the groups, though there is a significant fall between 1954 and 1956. This taken in conjunction with (1) above, makes it unlikely that the changes in weeks of absence per man shown in Table 4 represent a genuine effect.

TABLE 1

DISTRIBUTION OF VOLUNTEERS AND LAPSED EMPLOYEES IN 1954

\begin{tabular}{|c|c|c|c|c|c|}
\hline Exposure Group & No. Possible & Volunteers & $\%$ Volunteered & No. Lapsed & $\%$ Lapsed \\
\hline $\begin{array}{l}\text { No dust } \\
\text { Lime } \\
\text { Soda ash }\end{array}$ & $\begin{array}{l}218 \\
197 \\
305\end{array}$ & $\begin{array}{l}188 \\
134 \\
243\end{array}$ & $\begin{array}{l}86 \cdot 24 \\
68 \cdot 03 \\
79 \cdot 68\end{array}$ & $\begin{array}{l}30 \\
63 \\
62 \\
\end{array}$ & $\begin{array}{l}13 \cdot 76 \\
31.97 \\
20 \cdot 32\end{array}$ \\
\hline Total & 720 & 565 & 78.47 & 155 & $21 \cdot 53$ \\
\hline
\end{tabular}

TABLE 2

DISTRIBUTION OF VOLUNTEERS AND LAPSED EMPLOYEES IN 1956

\begin{tabular}{|c|c|c|c|c|c|c|c|}
\hline$\underset{\text { Group }}{\text { Exposure }}$ & $\begin{array}{c}\text { No. Possible } \\
\text { (1954 } \\
\text { Volunteers) }\end{array}$ & $\begin{array}{c}\text { Volunteers } 1956 \\
\text { (from 1954 } \\
\text { Volunteers) } \\
\end{array}$ & $\%$ Volunteered & No. Lapsed & $\%$ Lapsed & $\begin{array}{l}1956 \text { New } \\
\text { Volunteers }\end{array}$ & $\begin{array}{c}\text { Total } \\
\text { Volunteers }\end{array}$ \\
\hline $\begin{array}{l}\text { No dust } \\
\text { Lime } \\
\text { Soda ash }\end{array}$ & $\begin{array}{l}188 \\
134 \\
243 \\
\end{array}$ & $\begin{array}{r}89 \\
83 \\
167\end{array}$ & $\begin{array}{l}47 \cdot 34 \\
61 \cdot 95 \\
68 \cdot 72 \\
\end{array}$ & $\begin{array}{l}99 \\
51 \\
76\end{array}$ & $\begin{array}{l}52 \cdot 66 \\
38 \cdot 05 \\
31 \cdot 28 \\
\end{array}$ & $\begin{array}{l}37 \\
25 \\
62 \\
\end{array}$ & $\begin{array}{l}126 \\
108 \\
229 \\
\end{array}$ \\
\hline Total & 565 & 339 & $60 \cdot 00$ & 226 & $40 \cdot 67$ & 124 & 463 \\
\hline
\end{tabular}


TABLE 3

COMPARISON OF AVERAGE AGES OF VOLUNTEER AND LAPSED GROUPS IN 1954 AND 1956

\begin{tabular}{|c|c|c|c|c|c|c|c|c|}
\hline \multirow{2}{*}{$\begin{array}{c}\text { Exposure } \\
\text { Group }\end{array}$} & \multicolumn{4}{|c|}{1954} & \multicolumn{4}{|c|}{1956} \\
\hline & $\begin{array}{c}\text { No. of } \\
\text { Volunteers }\end{array}$ & $\begin{array}{c}\text { Average } \\
\text { Age }\end{array}$ & $\begin{array}{l}\text { No. } \\
\text { Lapsed }\end{array}$ & $\begin{array}{c}\text { Average } \\
\text { Age }\end{array}$ & $\begin{array}{l}\text { No. of } \\
\text { Volunteers }\end{array}$ & $\begin{array}{c}\text { Average } \\
\text { Age }\end{array}$ & $\begin{array}{c}\text { No. } \\
\text { Lapsed }\end{array}$ & $\begin{array}{c}\text { Average } \\
\text { Age }\end{array}$ \\
\hline $\begin{array}{l}\text { No dust } \\
\text { Lime } \\
\text { Soda ash }\end{array}$ & $\begin{array}{l}188 \\
134 \\
243\end{array}$ & $\begin{array}{l}43 \cdot 8 \\
43 \cdot 5 \\
41 \cdot 2\end{array}$ & $\begin{array}{l}30 \\
63 \\
62\end{array}$ & $\begin{array}{l}50 \cdot 8 \\
45 \cdot 0 \\
43 \cdot 8\end{array}$ & $\begin{array}{r}89 \\
83 \\
167\end{array}$ & $\begin{array}{l}42 \cdot 6 \\
44 \cdot 3 \\
41 \cdot 2\end{array}$ & $\begin{array}{l}69 \\
49 \\
52\end{array}$ & $\begin{array}{l}45 \cdot 9 \\
41 \cdot 6 \\
42 \cdot 3\end{array}$ \\
\hline
\end{tabular}

Examination of the sickness absence of the 1954 and 1956 groups shows that the " no-dust lapsed" subjects had a higher attack and sickness duration rate than other groups. The nine men aged 60 and over in the no-dust lapsed group contributed 17 attacks and 90 weeks lost. This will have materially affected the results. However, there appears from Table 4 to be no significant difference between the lapsed and volunteer groups in lime and soda ash works.

TABLE 4

TOTAL RESPIRATORY SICKNESS ABSENCE AS WEEKS LOST AND ATTACK RATE PER MAN OF VOLUNTEER AND LAPSED GROUPS IN 1954

\begin{tabular}{|c|c|c|c|c|}
\hline \multirow{2}{*}{$\begin{array}{l}\text { Exposure } \\
\text { Group }\end{array}$} & \multicolumn{2}{|c|}{ Lapsed Group } & \multicolumn{2}{|c|}{ Volunteer Group } \\
\hline & $\begin{array}{c}\text { Attacks } \\
\text { per Man }\end{array}$ & $\begin{array}{l}\text { Weeks Lost } \\
\text { per Man }\end{array}$ & $\begin{array}{l}\text { Attacks } \\
\text { per Man }\end{array}$ & $\begin{array}{l}\text { Weeks Lost } \\
\text { per Man }\end{array}$ \\
\hline $\begin{array}{l}\text { No dust } \\
\text { Lime } \\
\text { Soda ash }\end{array}$ & $\begin{array}{l}1.07 \\
0.73 \\
0.5\end{array}$ & $\begin{array}{l}4 \cdot 73 \\
2.55 \\
1 \cdot 43\end{array}$ & $\begin{array}{l}0.505 \\
0.619 \\
0.531\end{array}$ & $\begin{array}{l}1.65 \\
1.55 \\
1.38\end{array}$ \\
\hline
\end{tabular}

In 1956 examination of the sickness absence of the lapsed group shows that this is very similar both for attack and sickness duration rate compared with the volunteer group, though the volunteer lime group was higher than the others (Table 5).

\section{TABLE 5}

TOTAL RESPIRATORY SICKNESS ABSENCE AND ATTACK RATE PER MAN OF VOLUNTEER AND LAPSED GROUPS IN 1956

\begin{tabular}{l|c|c|c|c}
\hline \multirow{2}{*}{$\begin{array}{c}\text { Exposure } \\
\text { Group }\end{array}$} & \multicolumn{2}{|c|}{ Lapsed Group } & \multicolumn{2}{c}{ Volunteer Group } \\
\cline { 2 - 5 } & $\begin{array}{c}\text { Attacks } \\
\text { per Man }\end{array}$ & $\begin{array}{c}\text { Weeks Lost } \\
\text { per Man }\end{array}$ & $\begin{array}{c}\text { Attacks } \\
\text { per Man }\end{array}$ & $\begin{array}{c}\text { Weeks Lost } \\
\text { per Man }\end{array}$ \\
\hline No dust & 0.56 & 1.71 & 0.507 & 1.56 \\
Lime & 0.53 & 1.43 & 1.10 & 2.21 \\
Soda ash & 0.69 & 2.13 & 0.611 & 1.39 \\
\hline
\end{tabular}

\section{Evaluation of Sample}

The workers in soda ash from works $B$ and $C$ and workers in lime from works $\mathrm{A}, \mathrm{B}$, and $\mathrm{C}$ were the two dust groups which were to be compared with those from control works $D$, which had no dust. Table 6 shows that these groups were similar in age and physique.

In 1956 the sample was obtained as before and the same volunteers and any others were asked to attend.
TABLE 6

MEAN AGE, HEIGHT, AND WEIGHT OF THE THREE GROUPS IN 1954

\begin{tabular}{l|c|c|c|c}
\hline $\begin{array}{c}\text { Exposure } \\
\text { Group }\end{array}$ & No. & $\begin{array}{c}\text { Mean Age } \\
\text { (yr.) }\end{array}$ & $\begin{array}{c}\text { Height } \\
\text { (in.) }\end{array}$ & $\begin{array}{c}\text { Weight } \\
\text { (lb.) }\end{array}$ \\
\hline No dust & 188 & 43.89 & 68.02 & $155 \cdot 2$ \\
Lime & 134 & 43.46 & 67.99 & $149 \cdot 5$ \\
Soda ash & 243 & 41.19 & 68.17 & 150.5 \\
\hline
\end{tabular}

The numbers and mean ages of those who volunteered in 1956 are shown in Table 7.

TABLE 7

MEAN AGE OF THREE GROUPS IN 1956

\begin{tabular}{c|c|c}
\hline Exposure Group & No. & Mean Age (yr.) \\
\hline No dust & 126 & $42 \cdot 5$ \\
Lime & 108 & $45 \cdot 5$ \\
Soda ash & 229 & $42 \cdot 8$ \\
\hline
\end{tabular}

\section{Test Methods}

Industrial History. - Note was made of a number of characteristics, e.g., age, height, weight, and smoking habits, of each volunteer at the time of the test.

The type of exposure, whether to soda ash, lime, or no dust was also noted. The duration of years of exposure to each dusty or non-dusty atmosphere was recorded. As all men were coded for these works the exposure can be considered pure.

Physiological Test.-A minimum rest period of two to three minutes was allowed. Where any obvious dyspnoea or cough was present before the test, the subject waited until the breathing had returned to normal or the cough ceased.

The apparatus used was a simple spirometer with a constant speed kymograph. The subject was seated facing the spirometer but unable to see the tracings on the drum. After the subject had taken a deep breath he blew strongly through the mouthpiece. Using a protractor and carriage, the vital capacity and the expiratory flow rate were calculated. The average of the best three and the best result were recorded for both the vital capacity and the expiratory flow rate. The volumes were corrected to standard temperature and pressure.

Sickness Absence.-The names of employees certified sick by their own doctors were sent via the labour departments to the health visitors. The health visitors' records were used whenever possible in order to obtain a precise diagnosis; when not available the labour department records were used. In this way all employees' 
TABLE 8

AGE AND DURATION OF EXPOSURE OF THE EMPLOYEES IN THE THREE GROUPS IN 1954

\begin{tabular}{|c|c|c|c|c|c|c|c|c|c|c|c|c|c|c|c|}
\hline \multirow{3}{*}{$\begin{array}{c}\text { Exposure } \\
\text { (Years) }\end{array}$} & \multicolumn{5}{|c|}{ No Dust } & \multicolumn{5}{|c|}{ Lime } & \multicolumn{5}{|c|}{ Soda Ash } \\
\hline & \multicolumn{5}{|c|}{ Age Groups } & \multicolumn{5}{|c|}{ Age Groups } & \multicolumn{5}{|c|}{ Age Groups } \\
\hline & $20-$ & $30-$ & $40-$ & $50-$ & $60-$ & $20-$ & $30-$ & $40-$ & $50-$ & $60-$ & $20-$ & $30-$ & $40-$ & $50-$ & $60-$ \\
\hline $\begin{array}{l}6- \\
11- \\
21- \\
31- \\
41-\end{array}$ & $\begin{array}{l}40 \\
- \\
-\end{array}$ & $\begin{array}{l}31 \\
- \\
-\end{array}$ & $\begin{array}{l}36 \\
12 \\
1 \\
-\end{array}$ & $\begin{array}{r}20 \\
25 \\
2 \\
3 \\
1\end{array}$ & $\begin{array}{c}3 \\
8 \\
5 \\
1\end{array}$ & $\begin{array}{l}11 \\
- \\
-\end{array}$ & $\begin{array}{r}49 \\
1 \\
- \\
-\end{array}$ & $\begin{array}{r}28 \\
7 \\
2 \\
- \\
-\end{array}$ & $\begin{array}{r}11 \\
7 \\
7 \\
2 \\
1\end{array}$ & $\begin{array}{l}1 \\
1 \\
2 \\
3 \\
1\end{array}$ & $\begin{array}{r}40 \\
6 \\
- \\
-\end{array}$ & $\begin{array}{r}71 \\
6 \\
1 \\
- \\
-\end{array}$ & $\begin{array}{r}38 \\
14 \\
9 \\
1 \\
-\end{array}$ & $\begin{array}{r}13 \\
12 \\
15 \\
5 \\
1\end{array}$ & $\begin{array}{l}1 \\
2 \\
4 \\
2 \\
2\end{array}$ \\
\hline
\end{tabular}

TABLE 9

AGE AND DURATION OF EXPOSURE OF THE EMPLOYEES IN THE THREE GROUPS IN 1956

\begin{tabular}{|c|c|c|c|c|c|c|c|c|c|c|c|c|c|c|c|}
\hline \multirow{3}{*}{$\underset{\text { (Years) }}{\text { Exposure }}$} & \multicolumn{5}{|c|}{ No Dust } & \multicolumn{5}{|c|}{ Lime } & \multicolumn{5}{|c|}{ Soda Ash } \\
\hline & \multicolumn{5}{|c|}{ Age Groups } & \multicolumn{5}{|c|}{ Age Groups } & \multicolumn{5}{|c|}{ Age Groups } \\
\hline & $20-$ & $30-$ & $40-$ & $50-$ & $60-$ & $20-$ & $30-$ & $40-$ & $50-$ & $60-$ & $20-$ & $30-$ & $40-$ & $50-$ & $60-$ \\
\hline $\begin{array}{r}6- \\
11- \\
21- \\
31- \\
41-\end{array}$ & $\begin{array}{r}23 \\
1 \\
- \\
-\end{array}$ & $\begin{array}{l}29 \\
- \\
-\end{array}$ & $\begin{array}{r}22 \\
2 \\
2 \\
-\end{array}$ & $\begin{array}{r}24 \\
11 \\
3 \\
1 \\
-\end{array}$ & $\begin{array}{r}-2 \\
4 \\
2 \\
\end{array}$ & $\frac{3}{-}$ & $\frac{31}{-}$ & $\begin{array}{r}30 \\
5 \\
1 \\
- \\
\end{array}$ & $\begin{array}{r}6 \\
10 \\
7 \\
1 \\
-\end{array}$ & $\begin{array}{l}2 \\
2 \\
4 \\
4 \\
2\end{array}$ & $\begin{array}{r}17 \\
2 \\
- \\
-\end{array}$ & $\begin{array}{r}73 \\
17 \\
1 \\
- \\
-\end{array}$ & $\begin{array}{r}33 \\
16 \\
6 \\
1 \\
\end{array}$ & $\begin{array}{r}15 \\
10 \\
16 \\
6 \\
1\end{array}$ & $\begin{array}{l}4 \\
3 \\
5 \\
3\end{array}$ \\
\hline
\end{tabular}

health records were obtained. The diagnoses were coded in accordance with the International Statistical Classification of Diseases. Hughes (1952) used this classification to indicate subgroups and two of his subgroups (upper and lower respiratory illness) were used for differentiation. Thus, the number of attacks and total weeks lost for each employee were ascertained.

\section{Results}

Industrial Dust Conditions.-The duration of exposure of the three exposure groups is shown in Tables 8 and 9. The concentrations of dust were determined by collecting the dust from a measured volume of air on a filter paper. The gradings of the dusts were measured by microscope counts on samples collected, on an electrostatic precipitator (Table 10). Representative points for dust collection were chosen. Most of the workers were placed in constant concentrations of lime dust and a central point was therefore chosen. Ash workers may be exposed to high or low concentrations depending on their work, and therefore both figures were noted. The advantageous effect of a good exhaust system is shown by the figures which do not indicate a high percentage of small particles.

TABLE 10

REPRESENTATIVE DUST PARTICLE CONCENTRATIONS IN COMPARABLE WORKING PLACES

\begin{tabular}{|c|c|c|c|c|}
\hline \multicolumn{2}{|c|}{ Works } & $\begin{array}{c}\text { Average Dust } \\
\text { Concentration } \\
\left(\frac{\mathrm{mg} .}{\mathrm{m}^{3}}\right)\end{array}$ & $\begin{array}{l}\text { Number of } \\
\text { Particles Less } \\
\text { than } 4.5 \mu \\
\text { per cu. } \mathrm{ft} . / \mathrm{air}\end{array}$ & $\begin{array}{l}\text { Particles Less } \\
\text { than } 4 \cdot 5 \mu \mu \\
\text { ( } \% \text { by weight) }\end{array}$ \\
\hline \multirow[t]{2}{*}{ Lime: } & $\mathbf{A}$ & $8 \cdot 82^{*}$ & 2,780 & \multirow{2}{*}{0.018} \\
\hline & C & $2 \cdot 1$ & 662 & \\
\hline \multirow[t]{2}{*}{ Soda Ash: } & B & $\begin{array}{l}184.5 \mathrm{max} . * \\
4.9 \mathrm{~min} .\end{array}$ & $\begin{array}{r}745,000 \\
19,800\end{array}$ & \multirow{2}{*}{0.215} \\
\hline & C & $\begin{array}{l}50.3 \mathrm{max} . \\
2.1 \mathrm{~min} .\end{array}$ & $\begin{array}{r}203,000 \\
8,500\end{array}$ & \\
\hline No Dust: & $\mathbf{D}$ & $0 \cdot 3$ & 89 & 0.017 \\
\hline
\end{tabular}

* The concentration was much reduced later by dust extraction equipment already present at works $C$.

Sickness Absence.-Table 11 shows the sickness experience in contrasted dust exposure groups.

There were no significant differences between exposure groups in the mean frequency and time

TABLE 11

MEAN FREQUENCY AND TIME LOSS IN 1954

\begin{tabular}{|c|c|c|c|c|c|c|c|c|c|}
\hline & \multicolumn{3}{|c|}{ No Dust Group } & \multicolumn{3}{|c|}{ Lime } & \multicolumn{3}{|c|}{ Soda Ash } \\
\hline & $\begin{array}{l}\text { Total No. } \\
\text { in Groups }\end{array}$ & $\begin{array}{c}\text { Attacks } \\
\text { per Man }\end{array}$ & $\begin{array}{l}\text { Weeks } \\
\text { Lost/Man }\end{array}$ & $\begin{array}{l}\text { Total No. } \\
\text { in Groups }\end{array}$ & $\begin{array}{l}\text { Attacks } \\
\text { per Man }\end{array}$ & $\begin{array}{c}\text { Weeks } \\
\text { Lost/Man }\end{array}$ & $\begin{array}{l}\text { Total No. } \\
\text { in Groups }\end{array}$ & $\begin{array}{c}\text { Attacks } \\
\text { per Man }\end{array}$ & $\begin{array}{l}\text { Weeks } \\
\text { Lost/Man }\end{array}$ \\
\hline $\begin{array}{l}\text { Upper } \\
\text { respiratory } \\
\text { illness } \\
\text { Lower } \\
\text { respiratory } \\
\text { illness }\end{array}$ & $\begin{array}{l}188 \\
188\end{array}$ & $\begin{array}{l}0.505 \\
0.181\end{array}$ & $\begin{array}{l}1.65 \\
0.856\end{array}$ & $\begin{array}{l}134 \\
134\end{array}$ & $\begin{array}{l}0.619 \\
0.164\end{array}$ & $\begin{array}{l}1.552 \\
0.604\end{array}$ & $\begin{array}{l}243 \\
243\end{array}$ & $\begin{array}{l}0.531 \\
0.152\end{array}$ & $\begin{array}{l}1.38 \\
0.514\end{array}$ \\
\hline
\end{tabular}


TABLE 12

MEAN FREQUENCY AND TIME LOSS IN 1954 (95\% CONFIDENCE LIMITS)

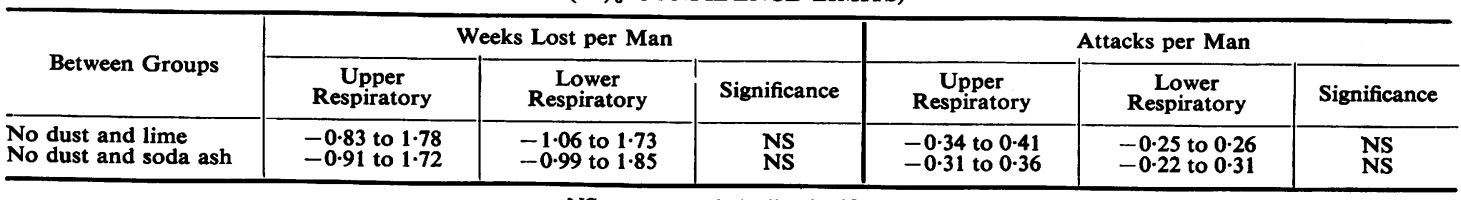

NS = not statistically significant

TABLE 13

MEAN FREQUENCY AND TIME LOSS IN 1956

\begin{tabular}{|c|c|c|c|c|c|c|c|c|c|}
\hline & \multicolumn{3}{|c|}{ No Dust Group } & \multicolumn{3}{|c|}{ Lime } & \multicolumn{3}{|c|}{ Soda Ash } \\
\hline & $\begin{array}{l}\text { Total No. } \\
\text { in Groups }\end{array}$ & $\begin{array}{c}\text { Attacks } \\
\text { per Man }\end{array}$ & $\begin{array}{c}\text { Weeks } \\
\text { Lost/Man }\end{array}$ & $\begin{array}{l}\text { Total No. } \\
\text { in Groups }\end{array}$ & $\begin{array}{c}\text { Attacks } \\
\text { per Man }\end{array}$ & $\begin{array}{l}\text { Weeks } \\
\text { Lost/Man }\end{array}$ & $\begin{array}{l}\text { Total No. } \\
\text { in Groups }\end{array}$ & $\begin{array}{c}\text { Attacks } \\
\text { per Man }\end{array}$ & $\begin{array}{c}\text { Weeks } \\
\text { Lost/Man }\end{array}$ \\
\hline $\begin{array}{l}\text { Upper } \\
\text { respiratory } \\
\text { illness } \\
\text { Lower } \\
\text { respiratory } \\
\text { illness }\end{array}$ & $\begin{array}{l}126 \\
126\end{array}$ & $\begin{array}{l}0.508 \\
0.182\end{array}$ & $\begin{array}{l}1.56 \\
0.849\end{array}$ & $\begin{array}{l}108 \\
108\end{array}$ & $\begin{array}{l}0.805 \\
0.296\end{array}$ & $\begin{array}{l}2 \cdot 20 \\
1 \cdot 41\end{array}$ & $\begin{array}{l}229 \\
229\end{array}$ & $\begin{array}{l}0.611 \\
0.170\end{array}$ & $\begin{array}{l}1.39 \\
0.620\end{array}$ \\
\hline
\end{tabular}

TABLE 14

MEAN FREQUENCY AND TIME LOSS IN 1956 (95\% CONFIDENCE LIMITS)

\begin{tabular}{|c|c|c|c|c|c|c|}
\hline \multirow{2}{*}{ Between Groups } & \multicolumn{3}{|c|}{ Weeks Lost per Man } & \multicolumn{3}{|c|}{ Attacks per Man } \\
\hline & $\begin{array}{c}\text { Upper } \\
\text { Respiratory }\end{array}$ & $\begin{array}{c}\text { Lower } \\
\text { Respiratory }\end{array}$ & Significance & $\begin{array}{c}\text { Upper } \\
\text { Respiratory }\end{array}$ & $\begin{array}{c}\text { Lower } \\
\text { Respiratory }\end{array}$ & Significance \\
\hline $\begin{array}{l}\text { No dust and lime } \\
\text { No dust and soda ash }\end{array}$ & $\begin{array}{r}-0.85 \text { to } 1.99 \\
1.10 \text { to } 1.20\end{array}$ & $\begin{array}{l}-0.87 \text { to } 2.08 \\
-1.16 \text { to } 1.62\end{array}$ & NS & $\begin{array}{l}-0.12 \text { to } 0.53 \\
-0.18 \text { to } 0.46\end{array}$ & $\begin{array}{l}-0.14 \text { to } 0.36 \\
-0.18 \text { to } 0.26\end{array}$ & NS \\
\hline
\end{tabular}

NS $=$ not statistically significant

lost because of respiratory sickness absence (Table 12).

Two years later the same exposure groups' sickness absence (Table 13) showed that there was still no significant difference between the groups (Table 14).

In both instances a detailed study of the agespecific attack rates showed no important divergence between dusty and non-dusty groups.

Results of Chest Radiography.-Chest radiographs of 20 workers with long service and exposure to dust showed no abnormality and no evidence of pneumoconiosis on miniature films.

\section{Physiological Tests}

Vital Capacity in 1954.- In 1954 the statistical analyses related vital capacity to age in years, height

TABLE 15

CHARACTERISTICS OF GROUPS AND MEAN VITAL CAPACITY IN 1954

\begin{tabular}{l|c|c|c|c|c}
\hline $\begin{array}{c}\text { Exposure } \\
\text { Groups }\end{array}$ & $\begin{array}{c}\text { No. } \\
\text { Examined }\end{array}$ & $\begin{array}{c}\text { Age } \\
\text { (yr.) }\end{array}$ & $\begin{array}{c}\text { Height } \\
\text { (in.) }\end{array}$ & $\begin{array}{c}\text { Weight } \\
\text { (lb.) }\end{array}$ & $\begin{array}{c}\text { V.C. } \\
\text { (litres) }\end{array}$ \\
\hline No dust & 188 & 43.89 & 68.02 & $155 \cdot 2$ & 3.96 \\
Lime & 134 & 43.46 & 67.99 & 149.5 & 3.93 \\
Soda ash & 243 & 41.19 & 68.17 & 150.5 & 4.01 \\
\hline
\end{tabular}

in inches, and weight in pounds, for the three exposure groups.

The regression coefficients (b) in the equation, $\mathrm{V}=\mathrm{b}_{1} \mathrm{~A}+\mathrm{b}_{2} \mathrm{H}+\mathrm{b}_{3} \mathrm{~W}+$ constant are shown in Table 16.

TABLE 16

REGRESSION COEFFICIENTS

\begin{tabular}{l|c|c|c}
\hline \multicolumn{1}{c|}{$\begin{array}{c}\text { Exposure } \\
\text { Groups }\end{array}$} & $b_{1}$ & $b_{2}$ & $b_{3}$ \\
\hline No dust & -0.0442 & 0.119 & -0.00188 \\
Lime & -0.0392 & 0.111 & -0.00117 \\
Soda ash & -0.0455 & 0.127 & -0.00073 \\
\hline
\end{tabular}

The regression coefficients for any group did not differ significantly from those of any other group, and they were, therefore, combined to give an overall estimate of the regression relationship, viz:-

$$
\mathrm{V}=-0.0420 \mathrm{~A}+0 \cdot 132 \mathrm{H}+\text { constant }
$$

The weight term is omitted since no coefficient differed significantly from zero.

The figures were further examined to see if a difference in vital capacity would appear in older men between the ages of 50 and 60 . The results from 17 men from each group are shown in Table 17. 
TABLE 17

CHARACTERISTICS OF GROUPS (OLDER MEN) AND MEAN VITAL CAPACITY

\begin{tabular}{l|c|c|c}
\hline $\begin{array}{c}\text { Exposure } \\
\text { Groups }\end{array}$ & $\begin{array}{c}\text { Age } \\
\text { (yr.) }\end{array}$ & $\begin{array}{c}\text { Height } \\
\text { (in.) }\end{array}$ & $\begin{array}{c}\text { Vital Capacity } \\
\text { (litres) }\end{array}$ \\
\hline No dust & 53.6 & 68.0 & 3.33 \\
Lime & 54.1 & 67.53 & 3.61 \\
Soda ash & 54.0 & 67.65 & 3.32 \\
\hline
\end{tabular}

The $t$ test again showed that the most extreme difference, i.e., that between the soda ash and lime areas, is not significant. It can, therefore, be concluded that there is no evidence that the vital capacity of men in these groups is affected by their environment.

Expiratory Flow Rate, 1954. - A regression analysis was done for expiratory flow rate similar to the analysis studying the dependence of vital capacity on age, height, and weight. The groups were the same. The regression coefficients (b) in the equation $\mathbf{M}=\mathrm{b}_{1} \mathrm{~A}+\mathrm{b}_{2} \mathrm{H}+\mathrm{b}_{3} \mathrm{~W}+$ constant are shown in Table 18.

TABLE 18

REGRESSION COEFFICIENTS

\begin{tabular}{l|c|c|c}
\hline \multicolumn{1}{c|}{$\begin{array}{c}\text { Exposure } \\
\text { Groups }\end{array}$} & $\mathrm{b}_{1}$ & $\mathrm{~b}_{2}$ & $\mathrm{~b}_{3}$ \\
\hline No dust & -1.25 & 2.38 & 0.20 \\
Lime & -1.34 & 2.52 & 0.09 \\
Soda ash & -1.23 & 1.63 & 0.11 \\
\hline
\end{tabular}

As before, weight did not appear to be a factor affecting E.F.R. nor did the regression coefficients differ significantly between groups either for age or height. The overall relationship was:

$$
\mathrm{M}=-1 \cdot 19 \mathrm{~A}+2 \cdot 34 \mathrm{H}+\text { constant }
$$

The average figures are shown in Table 19.

TABLE 19

CHARACTERISTICS OF GROUPS AND MEAN EXPIRATORY FLOW RATE IN 1954

\begin{tabular}{l|c|c|c|c|c}
\hline $\begin{array}{c}\text { Exposure } \\
\text { Groups }\end{array}$ & $\begin{array}{c}\text { No. } \\
\text { Examined }\end{array}$ & $\begin{array}{c}\text { Age } \\
\text { (yr.) }\end{array}$ & $\begin{array}{c}\text { Height } \\
\text { (in.) }\end{array}$ & $\begin{array}{c}\text { Weight } \\
\text { (lb.) }\end{array}$ & $\begin{array}{c}\text { E.F.R. } \\
\text { (litres/min.) }\end{array}$ \\
\hline No dust & 188 & 43.89 & 68.02 & 155.2 & 104.06 \\
Lime & 134 & 43.46 & 67.99 & $149 \cdot 5$ & 97.44 \\
Soda ash & 243 & 41.19 & 68.17 & 150.5 & 98.23 \\
\hline
\end{tabular}

If the expiratory flow rates are adjusted for age 42 years and height 68 in., common to all groups, they become:- No dust, 106.4; lime, 99.4; soda ash, 96.9.

The application of $t$ tests showed that the differences between soda ash and lime groups and the no-dust group were highly significant $(1.0 \%)$. This result was considered in relation to the radiographic and sickness-absence records of the exposure groups; it was felt that it should be confirmed in view of the negative findings in these two aspects of evidence of respiratory disability.

Thus, during the following year preparations were made to repeat the E.F.R. test on sample groups of 50 men from each of two works (B and C) and the control works $\mathrm{D}$, drawn strictly at random from those tested in 1954. All aspects of the test, except the weight and height recording, but including the scene and time of year, were the same as in 1954 .

The 1955 results (Table 20) were consistent with the linear regression relationship between E.F.R., age and height (M, A, and H) obtained in 1954.

TABLE 20

COMPARISON OF MEAN E.F.R. (1954-55)

\begin{tabular}{|c|c|c|c|}
\hline \multirow{2}{*}{$\begin{array}{l}\text { Exposure Groups } \\
(50 \text { in each })\end{array}$} & \multicolumn{2}{|c|}{$\begin{array}{l}\text { Average E.F.R. } \\
\text { (litres/min.) }\end{array}$} & \multirow{2}{*}{$\begin{array}{c}\text { Increase } \\
\text { (litres/min.) }\end{array}$} \\
\hline & 1954 & 1955 & \\
\hline $\begin{array}{l}\text { No dust } \\
\text { Soda ash: works C } \\
\text { Soda ash: works B }\end{array}$ & $\begin{array}{l}103 \cdot 6 \\
103 \cdot 3 \\
94 \cdot 04\end{array}$ & $\begin{array}{l}105 \cdot 8 \\
115 \cdot 0 \\
101 \cdot 0\end{array}$ & $\begin{array}{r}2 \cdot 2 \\
11 \cdot 7 \\
7 \cdot 0\end{array}$ \\
\hline
\end{tabular}

The marked increase in the E.F.R. in both groups exposed to soda ash compared with the nondust group nullified any statistical difference found in 1954. This result was also remarkable as a slight fall in the E.F.R. should theoretically have been expected in all groups because of increase in age. It was, therefore, imperative to repeat the entire test in 1956 in order to confirm the 1955 findings. Thus, at the same time of year (July) and at the same site, the E.F.R. test was performed in exactly the same way as before. The 1954 volunteers were encouraged to repeat the test. The numbers obtained are shown in Table 21, together with the average E.F.R.

TABLE 21

COMPARISON OF MEAN E.F.R. (1954-56)

\begin{tabular}{l|c|c|c|c}
\hline \multirow{2}{*}{$\begin{array}{c}\text { Exposure } \\
\text { Groups }\end{array}$} & \multicolumn{2}{|c|}{1954} & \multicolumn{2}{c}{1956} \\
\cline { 2 - 5 } & $\begin{array}{c}\text { No. in } \\
\text { Group }\end{array}$ & $\begin{array}{c}\text { Average } \\
\text { E.F.R. } \\
(1 . / \text { min. })\end{array}$ & $\begin{array}{c}\text { No. in } \\
\text { Group }\end{array}$ & $\begin{array}{c}\text { Average } \\
\text { E.F.R. } \\
(1 . / \text { min. })\end{array}$ \\
\hline No dust & 188 & 104.06 & 89 & 106 \\
Lime & 134 & 97.44 & 83 & 100 \\
Soda ash & 243 & 98.23 & 167 & 104 \\
\hline
\end{tabular}

The results were on the average higher than those for 1954. For the means of these the average increase was 4.50 litres $/ \mathrm{min}$. $(95 \%$ confidence limits, 3.22 to 5.78), which suggests that there are no systematic differences between the groups. This conclusion was confirmed by an analysis of variance in which the variation in the group average for 1956 was compared with the variation within the groups. The variation between group averages was not significantly greater than would have been expected if the groups had been identical. 
Smoking Habits and Sickness Absence due to Respiratory Illness.-Oswald and Medvei (1955) in their investigation of London civil servants indicated the importance of smoking in respiratory disorders, particularly bronchitis. This has been confirmed by Doll and Bradford Hill (1956).

TABLE 22

MEAN CIGARETTES PER DAY OF EXPOSURE GROUPS IN 1956

\begin{tabular}{l|c|c}
\hline Exposure Group & Number in Group & Cigarettes per Day \\
\hline No dust & 126 & $12 \cdot 7$ \\
Lime & 108 & $12 \cdot 3$ \\
Soda ash & 229 & $13 \cdot 1$ \\
\hline
\end{tabular}

A comparison of the smoking habits of the three occupational groups in 1956 showed no difference (Table 22). The respiratory sickness absence attack rate for the three groups provides an indication of the effect of smoking (Table 23), based on one year's experience.

TABLE 23

SMOKING RELATED TO TOTAL RESPIRATORY SICKNESS (UPPER AND LOWER RESPIRATORY ILLNESS) ABSENCE IN 1956 (ATTACK RATE)

\begin{tabular}{|c|c|c|c|}
\hline \multirow[b]{2}{*}{$\underset{\text { Group }}{\text { Exposure }}$} & \multicolumn{3}{|c|}{ Attacks per Man } \\
\hline & $\begin{array}{c}0 \text { to } 5 \\
\text { Cigarettes } \\
\text { per Day }\end{array}$ & $\begin{array}{c}6 \text { to } 20 \\
\text { Cigarettes } \\
\text { per Day }\end{array}$ & $\begin{array}{c}\text { Over } 20 \\
\text { Cigarettes } \\
\text { per Day }\end{array}$ \\
\hline $\begin{array}{l}\text { No dust } \\
\text { Lime } \\
\text { Soda ash }\end{array}$ & $\begin{array}{l}0.548 \\
1.52 \\
0.692\end{array}$ & $\begin{array}{l}0.847 \\
1.00 \\
0 \cdot 806\end{array}$ & $\begin{array}{l}0.682 \\
0.875 \\
0.823\end{array}$ \\
\hline
\end{tabular}

Table 24 shows the $95 \%$ confidence limits between the three smoking groups.

As there appeared to be a slight possibility of some significance in the no dust and lime groups, the analysis was repeated for the two groups 0 to 5 and over 21 cigarettes per day. The result is shown in Table 25.

There does not appear to be any significant difference in the total respiratory sickness absence between the three exposure groups attributable to smoking.
TABLE 25

$95 \%$ CONFIDENCE LIMITS BETWEEN SMOKING AND TOTAL RESPIRATORY SICKNESS ABSENCES (MEAN FREQUENCY)

\begin{tabular}{l|c|c}
\hline $\begin{array}{c}\text { Exposure } \\
\text { Group }\end{array}$ & $\begin{array}{c}\text { Between } 0 \text { to } 5 \text { and over } 21 \\
\text { Cigarettes per Day }\end{array}$ & Significance \\
\hline No dust & -0.593 to +0.909 & NS \\
Lime & -0.432 to +2.801 & NS \\
Soda ash & -0.526 to +0.720 & NS \\
All areas & -0.539 to +0.805 & NS \\
\hline
\end{tabular}

$\mathbf{S}=$ statistically significant. $\mathrm{NS}=$ not statistically significant

Smoking Habits and Respiratory Tests. - A combined regression of expiratory flow rate on age and height (disregarding smoking) was worked out. This gave an average E.F.R. of $109 \cdot 6$ litres per minute; average age, 43.7 years; average height, 68.2 inches. The regression equation of E.F.R. (M) on age (X) and height $\left(\mathrm{X}_{2}\right)$ becomes:

$$
\mathrm{M}=-1 \cdot 27(\mathrm{X})+3 \cdot 86\left(\mathrm{X}_{2}\right)-98 \cdot 1 \text {. }
$$

The $95 \%$ confidence limits for the two constants are:

$$
\mathrm{b}=-1 \cdot 20 \text { to }-1 \cdot 35 . \quad \mathrm{c}=+3 \cdot 44 \text { to }+4 \cdot 28 \text {. }
$$

These slopes do not differ significantly from the 1955 random sample.

Tables 26 and 27 (Figs. 1 and 2) give the mean E.F.R. for the three smoking groups according to age and height.

Separate regressions were fitted to each smoking group.

The differences are significant, and indicate that moderate smoking (six to 20 cigarettes/day) increases the effect of both age and height. The effect of smoking in reducing E.F.R. is greatest for older and shorter men (Figs. 1 and 2). The group of men who smoke more than 20 cigarettes a day showed even steeper regressions, but as the number of men in the group was small and the results found were more variable than in the other groups, the differences in the regression constants are not statistically significant.

\section{Discussion}

Respiratory function tests have rarely been used on men exposed to alkaline dusts. However, Kadlec

TABLE 24

95\% CONFIDENCE LIMITS BETWEEN SMOKING AND TOTAL RESPIRATORY SICKNESS ABSENCES

\begin{tabular}{|c|c|c|c|c|}
\hline \multirow{3}{*}{ Exposure Group } & \multicolumn{4}{|c|}{1956} \\
\hline & \multicolumn{2}{|c|}{ Cigarettes per Day } & \multicolumn{2}{|c|}{ Cigarettes per Day } \\
\hline & Between 0 to 5 and 6 to 20 & Significance & Between 6 to 20 and over 21 & Significance \\
\hline $\begin{array}{l}\text { No dust } \\
\text { Lime } \\
\text { Soda ash } \\
\text { All areas }\end{array}$ & $\begin{array}{l}-0.07 \text { to }+1.09 \\
-1.01 \text { to }+2.16 \\
-0.18 \text { to }+0.92 \\
-0.26 \text { to }+0.27\end{array}$ & $\begin{array}{c}\text { Possible S } \\
\text { NS } \\
\text { NS } \\
\text { NS }\end{array}$ & $\begin{array}{l}-0.53 \text { to }+1.23 \\
-0.09 \text { to }+1.31 \\
-0.028 \text { to }+1.22 \\
-0.14 \text { to }+1.05\end{array}$ & $\begin{array}{c}\text { NS } \\
\text { Possible S } \\
\text { NS } \\
\text { NS }\end{array}$ \\
\hline
\end{tabular}
(MEAN FREQUENCY) 
TABLE 26

MEAN E.F.R. IN LITRES PER MINUTE BY AGE IN THREE SMOKING GROUPS

\begin{tabular}{|c|c|c|c|c|c|c|}
\hline \multirow{2}{*}{$\begin{array}{l}\text { Age Group } \\
\text { (Years) }\end{array}$} & \multicolumn{2}{|c|}{$\begin{array}{c}0 \text { to } 5 \text { Cigarettes } \\
\text { per Day }\end{array}$} & \multicolumn{2}{|c|}{$\begin{array}{c}6 \text { to } 20 \text { Cigarettes } \\
\text { per Day }\end{array}$} & \multicolumn{2}{|c|}{$\begin{array}{c}\text { Over } 20 \text { Cigarettes } \\
\text { per Day }\end{array}$} \\
\hline & $\begin{array}{l}\text { Number } \\
\text { in Group }\end{array}$ & $\begin{array}{l}\text { Mean } \\
\text { E.F.R. }\end{array}$ & $\begin{array}{l}\text { Number } \\
\text { in Group }\end{array}$ & $\begin{array}{l}\text { Mean } \\
\text { E.F.R. }\end{array}$ & $\begin{array}{l}\text { Number } \\
\text { in Group }\end{array}$ & $\begin{array}{l}\text { Mean } \\
\text { E.F.R. }\end{array}$ \\
\hline $\begin{array}{l}20- \\
30- \\
40- \\
50- \\
60-\end{array}$ & $\begin{array}{l}11 \\
32 \\
32 \\
28 \\
12\end{array}$ & $\begin{array}{r}118 \\
110 \\
102 \\
86 \\
80\end{array}$ & $\begin{array}{r}33 \\
111 \\
68 \\
79 \\
21\end{array}$ & $\begin{array}{r}122 \\
108 \\
98 \\
84 \\
71\end{array}$ & $\begin{array}{r}2 \\
8 \\
18 \\
4 \\
4\end{array}$ & $\begin{array}{r}117 \\
100 \\
98 \\
78 \\
56\end{array}$ \\
\hline
\end{tabular}

TABLE 27

MEAN E.F.R. IN LITRES PER MINUTE BY HEIGHT IN THREE SMOKING GROUPS

\begin{tabular}{|c|c|c|c|c|c|c|}
\hline \multirow{2}{*}{$\begin{array}{l}\text { Height } \\
\text { (Inches) }\end{array}$} & \multicolumn{2}{|c|}{$\begin{array}{l}0 \text { to } 5 \text { Cigarettes } \\
\text { per Day }\end{array}$} & \multicolumn{2}{|c|}{$\begin{array}{l}6 \text { to } 20 \text { Cigarettes } \\
\text { per Day }\end{array}$} & \multicolumn{2}{|c|}{$\begin{array}{c}\text { Over } 20 \text { Cigarettes } \\
\text { per Day }\end{array}$} \\
\hline & $\begin{array}{l}\text { Number } \\
\text { in Group }\end{array}$ & $\begin{array}{l}\text { Mean } \\
\text { E.F.R. }\end{array}$ & $\begin{array}{c}\text { Number } \\
\text { in Group }\end{array}$ & $\begin{array}{c}\text { Mean } \\
\text { E.F.R. }\end{array}$ & $\begin{array}{c}\text { Number } \\
\text { in Group }\end{array}$ & $\begin{array}{l}\text { Mean } \\
\text { E.F.R. }\end{array}$ \\
\hline $\begin{array}{l}64- \\
66- \\
68- \\
70-\end{array}$ & $\begin{array}{l}28 \\
35 \\
31 \\
21\end{array}$ & $\begin{array}{r}97 \\
91 \\
108 \\
101\end{array}$ & $\begin{array}{r}50 \\
75 \\
112 \\
75\end{array}$ & $\begin{array}{r}89 \\
88 \\
101 \\
109\end{array}$ & $\begin{array}{r}6 \\
9 \\
9 \\
12\end{array}$ & $\begin{array}{c}63 \\
88 \cdot 5 \\
92 \cdot 5 \\
113\end{array}$ \\
\hline
\end{tabular}

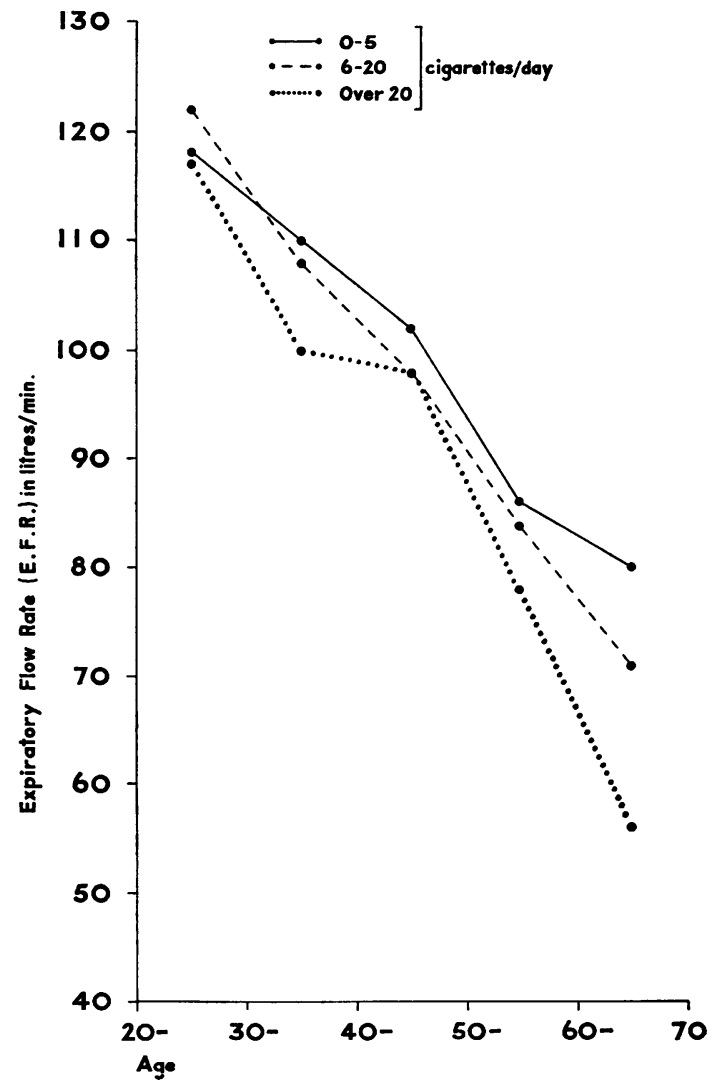

FIG. 1.
FIGs. 1 and 2.-The mean E.F.R. for the three smoking groups according to age and height.

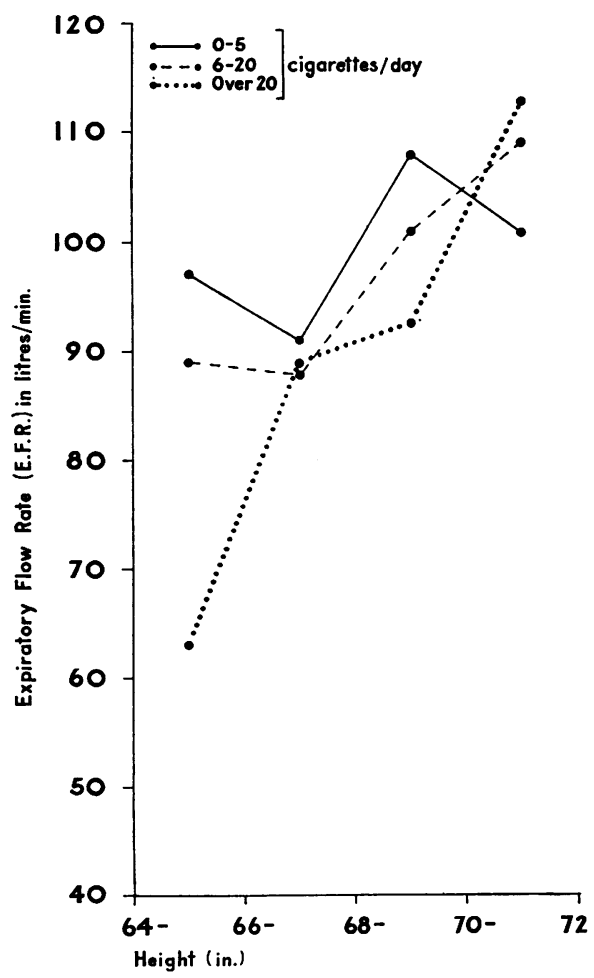

FIG. 2 
and Vyskocil (1950) employed the fast expiratory vital capacity method for evaluation of the differences between three groups of workers in lime-containing cement. They had previously been graded by other functional tests and clinical and radiographic examinations into the three groups: slight bronchitis, advanced bronchitis, and doubtful emphysema. In 97 men who had been exposed to the dust for more than seven years, Kadlec and Vyskocil found statistically significant differences between the groups. Kazantzis and Buxton (1956) using the same test found no difference between control groups and groups exposed to cadmium fume. Gilson et al. (1955) considered that this type of test might be useful in assessing disability in pneumoconiosis particularly when compensation issues were at stake.

In the present paper the respiratory function of workers in alkaline dusts was compared with a control group using the expiratory flow rate test and, in contradistinction to Kadlec and Vyskocil's work, the affected groups were not previously subdivided aecording to respiratory disability. The findings in 1954 of a real difference in E.F.R. and no difference in vital capacity between the groups with a similar E.F.R. in the succeeding two years emphasized the importance of both the lack of morbidity and radiological evidence of effects from the dust. The E.F.R. test was chosen for its simplicity and had been used many times before the survey, but the stimulating effect of a group of men on each volunteer's efforts had not been appreciated. The uniform results obtained from the control group (works D) confirmed this view.

Sickness absence studies indicated that dust, particularly lime, does slightly increase the respiratory morbidity, a view which is in accord with that of Oswald and Medvei (1955).

Smoking habits coupled with respiratory morbidity and function tests indicated that heavy smoking combined with age and height in being significantly correlated with the E.F.R. This finding is similar to that of Whitfield, Melville Arnott, and Waterhouse (1951) who found a reduction in lung volume in heavy smokers. The older and shorter men had a greater impairment of the E.F.R. due to smoking. Respiratory sickness absence was also increased in heavy smokers. The implication from these findings was that, although the dusts concerned in the working environment do cause some increase in respiratory illness, their significance in the production of respiratory disability, either functional or pathological, is not as important as the number of cigarettes smoked daily.

My thanks are due to members of the Research Department of I.C.I. Ltd., Alkali Division, for much valuable help including $p \mathrm{H}$ measurements, and to the Division Board of Directors for permission to publish; also to Dr. D. A. K. Cassells for his encouragement and advice.

\section{REFERENCES}

Archibald, R. McL. (1954). Brit. J. industr. Med. 11, 31. Bridge Davis, S., and Nagelschmidt, G. (1956). Ibid., 13, 6 Bridge Davis, S., and Nagelschmid.
Doig, A. T. (1955). Ibid., 12, 206.

Doig, A. T. (1955). Ibid., 12, 206.

Gardner, L. U., Durkan, T. M., Brumfiel, D. M., and Sampson, H. L. (1939). J. industr. Hyg., 21, 279.

Garrad, J. (1949). Brit. J. industr. Med., 6, 221.

Gilson, J. C., Hugh-Jones, P., Oldham, P. D., and Meade, F. (1955). Spec. Rep. Ser. med. Res. Coun. (Lond.), No. 290.

Hughes, J. P. W. (1952). Brit. J. industr. Med., 9, 264.

Hunter, D. (1955). The Diseases of Occupations. English University Press, London.

Kadlec, K., and Vyskocil, J. (1950). Pracov. Lék., 2, 348.

Kazantzis, G., and Buxton, R. St. J. (1956). Brit. J. industr. Med., 13, 30, 36.

Kennedy, M. C. S. (1953). Thorax, 8, 73.

Marchand, M. (1944). Arch Mal. prof., 6, 132.

Motley, H. L., Lang, L. P., and Gordon, B. (1949). Amer. Rev. Tuberc., 59,270 .

Oswald, N. C., and Medvei, M. V. (1955). Lancet, 2, 843

Profazio, A., and Troisi, F. M. (1953). Folia med. Napoli, 36, 15.

Raymond, V., Sivadon, A., and Conil, P. (1952). Arch. Mal. Prof., 13, 169.

Registrar General (1931). Decennial Supplement England \& Wales, 1931. Part 11a Occupational Mortality, London, H.M.S.O.

Sander, O. A. (1958). A.M.A. Arch. industr. Hlth, 17,96.

Whitfield, A. G. W., Melville Arnott, W., and Waterhouse, J.A.H. (1951). Quart. J. Med., 20, 141 . 